\title{
THE SPLIT EJACULATE OF THE BOAR: CONTRIBUTIONS OF THE EPIDIDYMIDES AND SEMINAL VESICLES
}

\author{
U. LAVON* AND J. C. BOURSNELL \\ A.R.C. Unit of Reproductive Physiology and Biochemistry, Cambridge†
}

(Received 2nd September 1974)

\begin{abstract}
Summary. The epididymal and seminal vesicular contributions to splitejaculate fractions from boars were analysed for sperm concentration, glycerylphosphorylcholine (GPC), total-N, ethanol-soluble and insoluble $\mathrm{N}$, citrate, zinc and haemagglutinin. The same components were also determined in epididymal plasma (EP), vesicular secretion (VS) and whole seminal plasma (SP). Isoelectric focusing of protein patterns was studied in the fractions.

With the exception of haemagglutinin, the components were present to a major extent in either VS or EP and in lower concentrations in the other secretion. The parameters in VS or EP were positively correlated among themselves and negatively correlated with most of the parameters of the other fluid. The correlation coefficients were not significant in all cases for individual animals, but the degree of significance was greater for the over-all correlations.

The EP components were mainly secreted in the first three or four fractions, but occasionally from fraction four onwards. Those of VS were emitted during the entire ejaculation, the maximum occurring in the sperm-rich fraction or the immediately succeeding fraction. The first fractions were devoid of VS components in only one case.

The majority of the EP proteins could be identified electrophoretically in the sperm-rich fractions, but the protein patterns in the other fractions were similar to those of VS. The results are discussed and compared with previous findings.
\end{abstract}

\section{INTRODUGTION}

The semen of the boar differs from that of the ram and bull in several ways; the volume is large, the sperm concentration very low and ejaculation occurs in several waves, the process occupying several minutes (McKenzie, Miller \& Bauguess, 1938; Glover \& Mann, 1954). In the boar ejaculate, it is possible to

\footnotetext{
* Present address: Israel Chemicals Ltd, Hakirya, Tel Aviv, Israel.

$\uparrow$ Postal address: Animal Research Station, 307 Huntingdon Road, Cambridge CB3 0JQ.
} 
distinguish three major fractions, designated pre-sperm, sperm-rich and postsperm according to the sperm distribution. Most of the physiological and biochemical studies on the characteristics of fractionated (split) ejaculates have been limited to those of the main fractions (McKenzie et al., 1938; Glover, 1955; Archipovec, 1961; Johnson, Pursel \& Gerrits, 1969a, b), but in several cases semen has been collected according either to volume or time sequence (Glover \& Mann, 1954; Bialy \& Self, 1959; Einarsson, Crabo \& Ekman, 1970). The majority of the constituents which have been studied originate in the seminal vesicle secretion (VS), and have enabled an assessment to be made of the contribution of this gland to the various fractions (Glover \& Mann, 1954) and to the final volume of the ejaculate (Mann \& Glover, 1954).

Little attention has been given to the contribution of the epididymal plasma (EP) to the various fractions and in particular to the sperm-rich fraction which is so frequently used in insemination.

The chemical composition of EP, VS and seminal plasma (SP) has been studied by various investigators. The EP contains high levels of glycerylphosphorylcholine (GPG) (Dawson, Mann \& White, 1957; Mann, 1959) and a considerable proportion of the nitrogenous material was soluble in ethanol (Mann, 1959). The major constituents of the VS are citrate (Humphrey \& Mann, 1949), ergothioneine (Leone \& Mann, 1951; Mann \& Leone, 1953), inositol (Mann, 1951, 1954) and protein (Mann, 1959; Boursnell, Baronos, Briggs \& Butler, 1972). Boursnell \& Coombs (1966) reported the presence of a powerful haemagglutinin in boar VS, later identified as a mixture of proteins ('protein H') of high isoelectric point by Nelson \& Boursnell (1966), Boursnell \& Briggs (1969) and Lavon, Briggs \& Boursnell (1973). Boursnell et al. (1972) confirmed a high level of zinc in boar VS (first observed by Bertrand \& Vladesco, 1921), and also found a highly significant correlation between the zinc concentration and those of other substances characteristic of this fluid, particularly citrate and total N. The SP, a mixture of the secretions of various accessory sex glands, contained large quantities of all these components.

In addition, Lavon \& Boursnell (1971), Lavon, Boursnell \& Briggs (1972) and Lavon et al. (1973) have studied and characterized, by gel disc electrophoresis and isoelectric focusing on acrylamide gel, many discrete protein components of VS and EP. Striking differences were shown between the proteins arising from the seminal vesicles and the epididymides.

This work was undertaken to extend the results of the above studies and to investigate the contribution of many of the VS and EP components to the composition of the split ejaculate fractions, paying special attention to the sperm-rich fraction.

\section{MATERIALS AND METHODS}

\section{Collection of semen and ftuids}

Split ejaculate fractions, collected at 30-sec intervals from four adult boars (A, B, F and W), housed at the Animal Research Station, were immediately strained through muslin to remove the gel. The volume of each fraction was measured and the spermatozoa were counted in a haemocytometer. Whole 
semen was also collected from the same animals, at a different time, and the gel was separated.

The VS was obtained from seminal vesicle glands freshly excised from slaughterhouse material as described by Boursnell, Hartree \& Briggs (1970). Epididymal semen from freshly excised epididymides from the same carcasses was collected by the method of Lasley \& Bogart (1944) as described by Walton (1957).

The spermatozoa were separated by centrifugation $(10,000 \mathrm{~g}$ for $20 \mathrm{~min}$ at room temperature) and the supernatants were stored at $-25^{\circ} \mathrm{C}$ until required. The VS was similarly stored, after centrifugation to remove cell débris.

\section{Determination of total and ethanol-soluble nitrogen}

Total $\mathrm{N}$ was determined by the micro-Kjeldahl procedure described by Boursnell et al. (1970). Soluble $\mathrm{N}$ was similarly determined in supernatants of samples precipitated by addition of 2 vols redistilled ethanol (Boursnell, Briggs, Lavon \& Butler, 1973b). The ethanol-insoluble $\mathrm{N}$ was determined by difference.

\section{Determination of glycerylphosphorylcholine}

The supernatants of the ethanol-precipitated samples used for total $\mathrm{N}$ were taken to dryness and the residue was dissolved in water. Aliquots were hydrolysed in $\mathrm{N}-\mathrm{HCl}$ at $100^{\circ} \mathrm{C}$ for $20 \mathrm{~min}$ (Brooks, 1970) and the liberated choline was precipitated by ammonium reineckate (B.D.H. Chemicals, Poole) according to the method of Glick (1944). The absorbance of the final acetone solution of the choline reineckate salt was measured at $345 \mathrm{~nm}$ in an SP 500 spectrophotometer (Pye Unicam, Cambridge).

\section{Determination of citrate}

This was determined by a modification (Lindner \& Mann, 1960) of the method of Speck, Moulder \& Evans (1946).

\section{Determination of zinc}

This was determined after suitable dilution as described by Boursnell, Briggs, Lavon \& Butler (1973a) in an SP 90 atomic absorption spectrophotometer (Pye Unicam, Cambridge).

\section{Haemagglutinin titration}

This was carried out by serial doubling dilution in buffered saline $(0 \cdot 15$ $\mathrm{M}-\mathrm{NaCl}$ ) using a $1 \%(\mathrm{v} / \mathrm{v})$ suspension of washed sheep red cells (Boursnell, 1967).

\section{Isoelectric focusing}

This was performed on polyacrylamide-ampholine plates of $\mathrm{pH} 3$ to 10 (L.K.B. Instruments, South Croydon) which were prepared and used as described by Lavon \& Boursnell (1971) and by Lavon (1972). 
Statistical analysis of the results

The correlation coefficients between the various parameters were calculated according to the method described by Bliss (1967).

\section{RESULTS}

Concentration of components in boar vesicular secretion, epididymal plasma and seminal plasma

The mean contents of various components in VS and EP obtained from slaughterhouse material and in whole SP collected from the four boars providing the split ejaculates, together with the ratios between the concentrations of each of the components in the various secretions, are given in Table 1. The mean dilutions of the VS and EP in the SP during ejaculation were found to be $\times 6$ and $\times 30$, respectively.

Table 1. Mean concentrations ( $\mathrm{mg} / 100 \mathrm{ml}$ ) of GPC, total, ethanolsoluble and -insoluble nitrogen, citrate and zinc in samples of boar epididymal plasma, vesicular secretion and whole seminal plasma

\begin{tabular}{|c|c|c|c|c|c|c|}
\hline Sample & $G P C$ & $\begin{array}{c}\text { Total } \\
\text { nitrogen }\end{array}$ & $\begin{array}{c}\text { Soluble } \\
\text { nitrogen }\end{array}$ & $\begin{array}{l}\text { Insoluble } \\
\text { nitrogen }\end{array}$ & Citric acid & Zinc \\
\hline $\begin{array}{l}\text { Epididymal plasma } \\
\text { Mean } \\
\text { S.E.M. } \\
\text { Ratio* }\end{array}$ & $\begin{array}{c}2306 \\
236 \\
13 \cdot 10\end{array}$ & $\begin{array}{l}565 \\
18 \\
(1.00)\end{array}$ & $\begin{array}{l}336 \\
16 \\
8.62\end{array}$ & $\begin{array}{l}253 \\
25 \\
(1 \cdot 00)\end{array}$ & $\begin{array}{c}21 \cdot 1 \\
1 \cdot 2 \\
(1 \cdot 00)\end{array}$ & $\begin{array}{c}1.02 \\
0.58 \\
(1.00)\end{array}$ \\
\hline $\begin{array}{l}\text { Vesicular secretion } \\
\text { Mean } \\
\text { S.E.M. } \\
\text { Ratio* }\end{array}$ & $\begin{array}{l}176 \\
15 \\
(1 \cdot 00)\end{array}$ & $\begin{array}{c}1658 \\
91 \\
2.93\end{array}$ & $\begin{array}{l}39 \\
3 \\
(1 \cdot 00)\end{array}$ & $\begin{array}{c}1619 \\
91 \\
6.40\end{array}$ & $\begin{array}{l}756 \\
36 \\
35 \cdot 83\end{array}$ & $\begin{array}{c}21.5 \\
1.2 \\
21.08\end{array}$ \\
\hline $\begin{array}{l}\text { Seminal plasma } \\
\text { Mean } \\
\text { S.E.M. } \\
\text { Ratio* }\end{array}$ & $\begin{array}{c}114 \\
15 \\
0.65\end{array}$ & $\begin{array}{l}222 \\
58 \\
0.39\end{array}$ & $\begin{array}{c}27 \cdot 1 \\
4 \cdot 4 \\
0 \cdot 69\end{array}$ & $\begin{array}{c}195 \\
54 \\
0.77\end{array}$ & $\begin{array}{l}153 \\
42 \\
7 \cdot 25\end{array}$ & $\begin{array}{l}2.00 \\
0.59 \\
1.96\end{array}$ \\
\hline
\end{tabular}

The seminal plasma samples were obtained from four boars. The epididymal plasma and vesicular secretion samples were obtained from slaughterhouse material.

* Ratios of these concentrations to the lower of the mean concentrations occurring in epididymal plasma or vesicular secretions.

Total quantities of the components in the split ejaculate fractions

The total number of spermatozoa and the total quantities of the components in the split ejaculate fractions are presented in Text-figs 1 to 4 which also give the volumes of the fractions. The concentrations of the components may be calculated from these results. The partial correlations between the various concentrations for the individual animals are given in Table 2 and the over-all correlations are given in Table 3.

Protein patterns in vesicular secretion, epididymal plasma and in the split ejaculate fractions

These isoelectric focusing patterns are shown in Pl. 1, Figs 1 to 14. 


\section{PLATE 1}

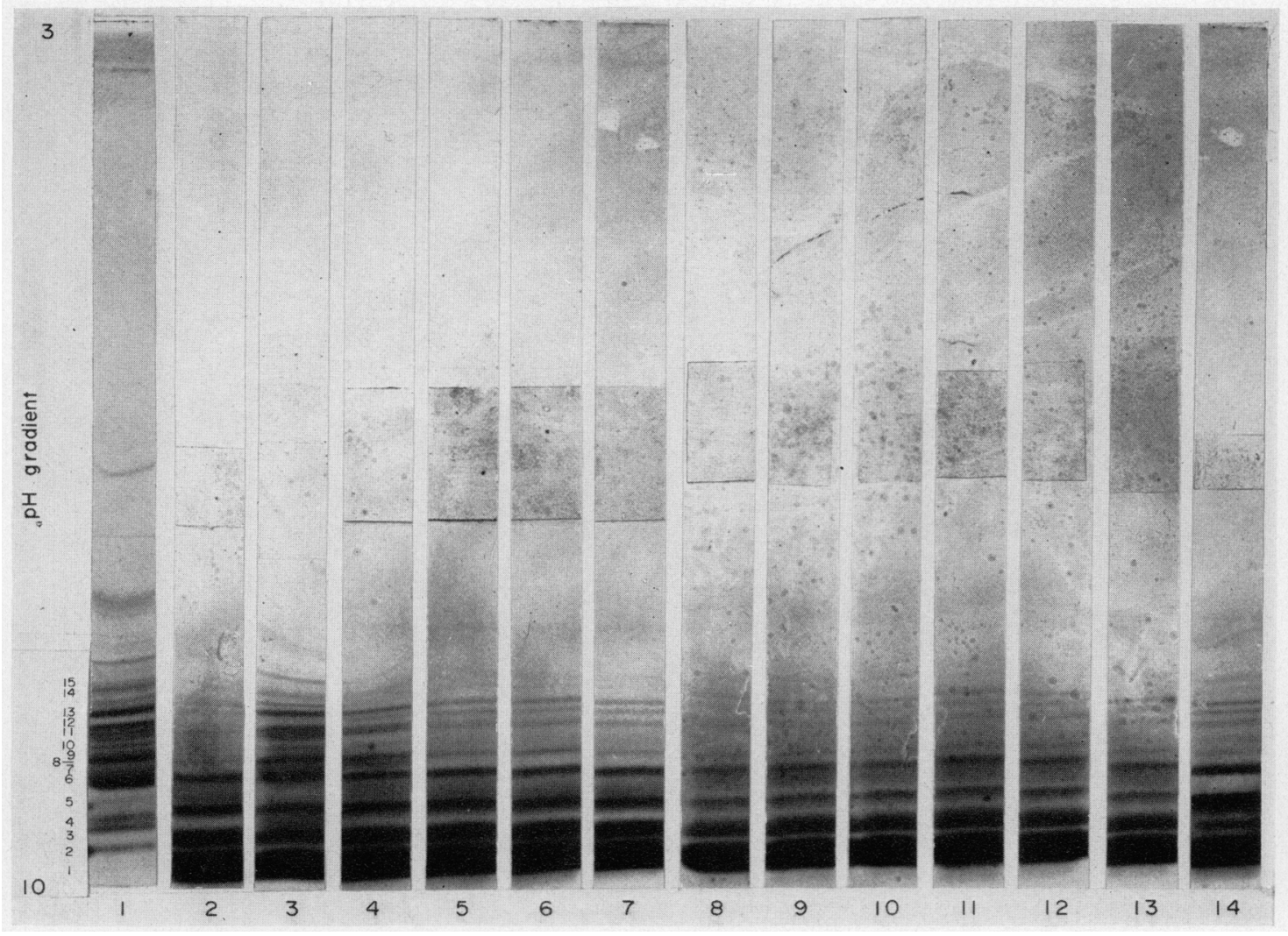

Protein patterns (band numbers on left of Fig. 1) obtained by isoelectric focusing on ampholine-acrylamide plates (pH 3 to 10 ).

Fig. 1. Boar epididymal plasma.

Figs 2 to 13. Fractions 1 to 12 of the split ejaculate of Boar A (13/7/71).

Fig. 14. Boar vesicular secretion.

(Facing p. 544) 


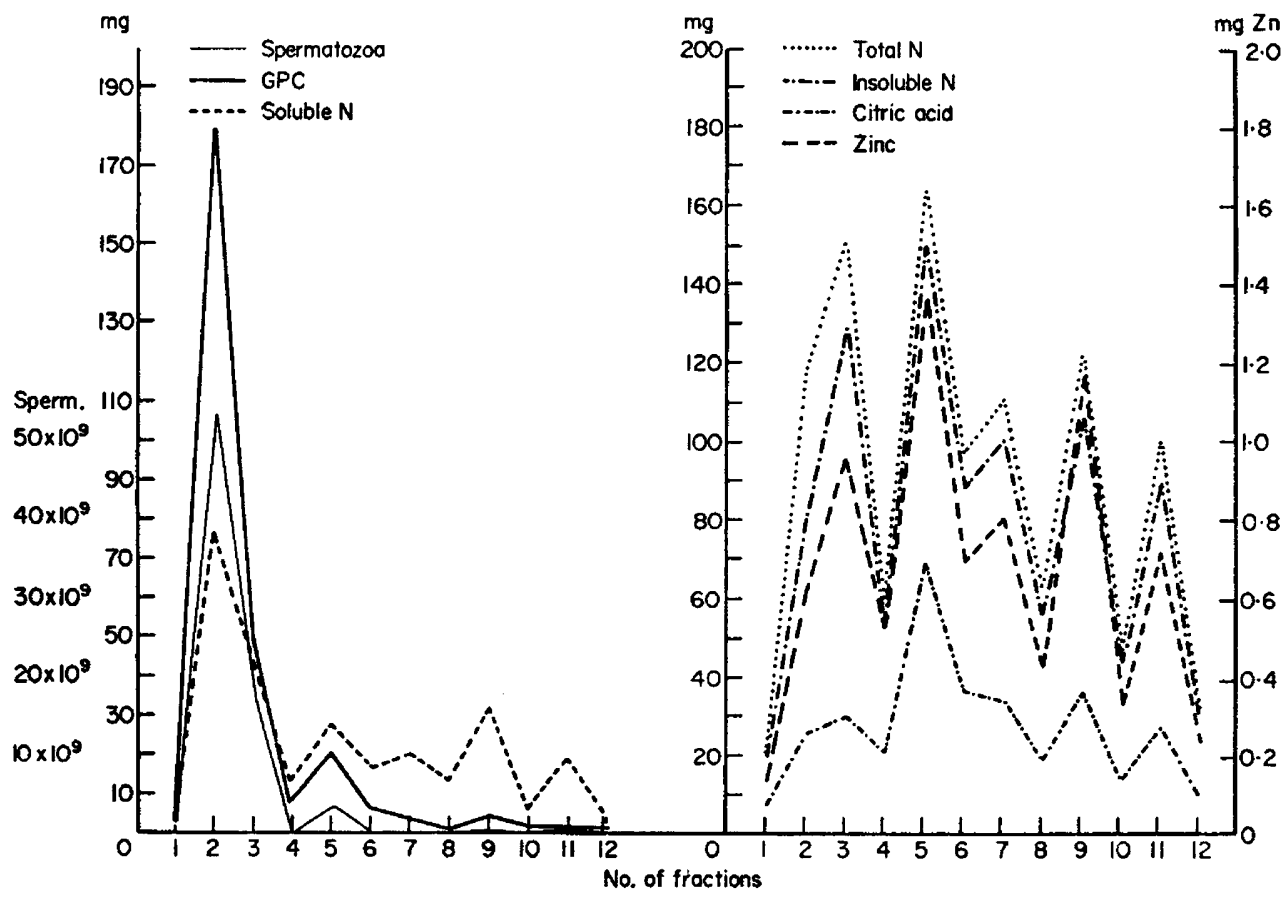

TExT-FIG. 1. Number of spermatozoa and total quantities of substances in fractions of a split ejaculate (Boar A, 13/7/71). The vols (mI) of the fractions in order were: $3 \cdot 0$, $47 \cdot 5,43 \cdot 0,17 \cdot 0,39 \cdot 5,23 \cdot 5,30 \cdot 0,20 \cdot 0,32 \cdot 0,9 \cdot 0,23 \cdot 5$ and $7 \cdot 5$.

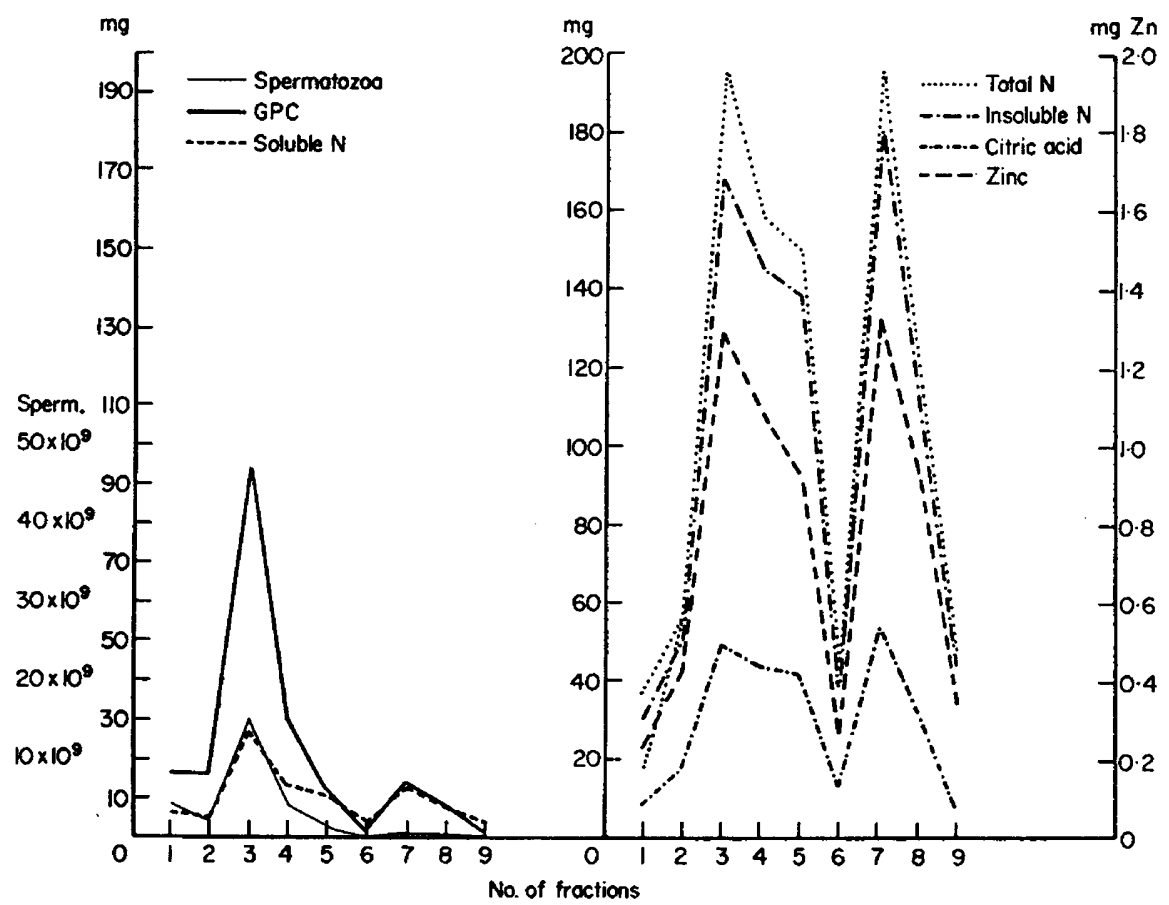

Text-F1G. 2. As Text-fig. 1. Values for Boar B (24/6/71). The vols (ml) of the fractions in order were: $19 \cdot 5,16 \cdot 5,52 \cdot 0,36 \cdot 0,34 \cdot 0,14 \cdot 0,47 \cdot 0,26 \cdot 0$ and $15 \cdot 0$. 


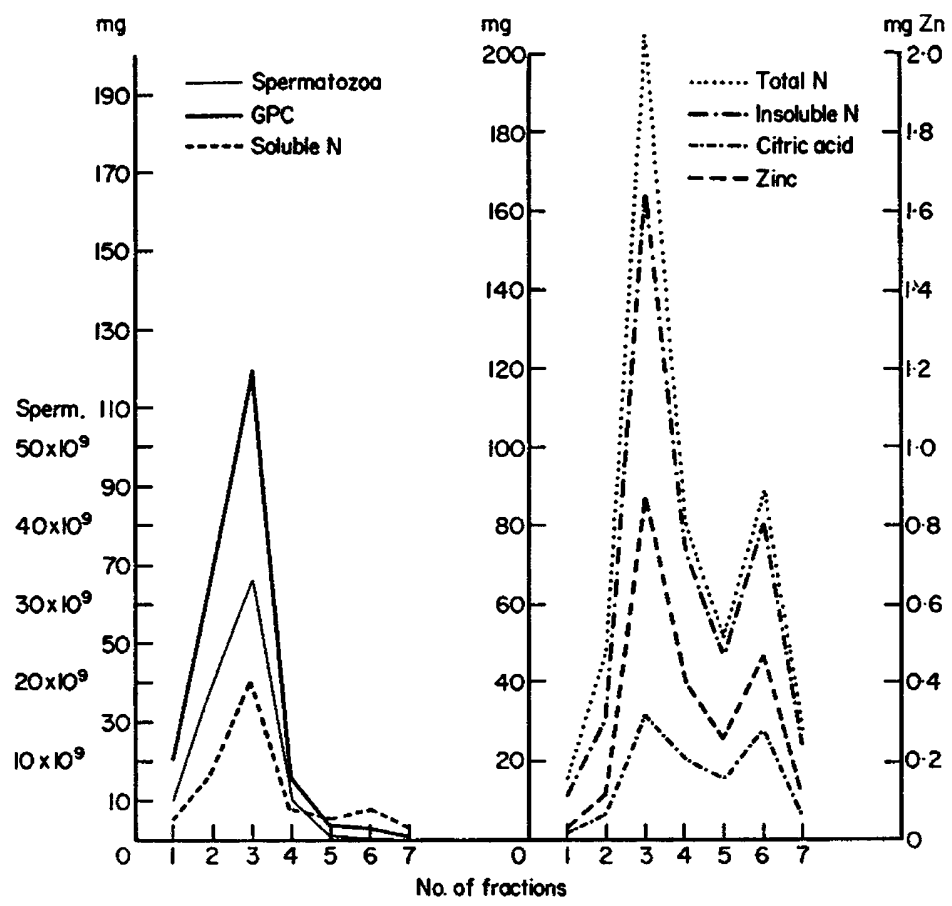

Text-Fig. 3. As Text-fig. 1. Values for Boar $\mathrm{F}(1 / 7 / 71)$. The vols (ml) of the fractions in order were: $15 \cdot 5,41 \cdot 0,82 \cdot 5,29 \cdot 0,22 \cdot 5,36 \cdot 0$ and $16 \cdot 0$.

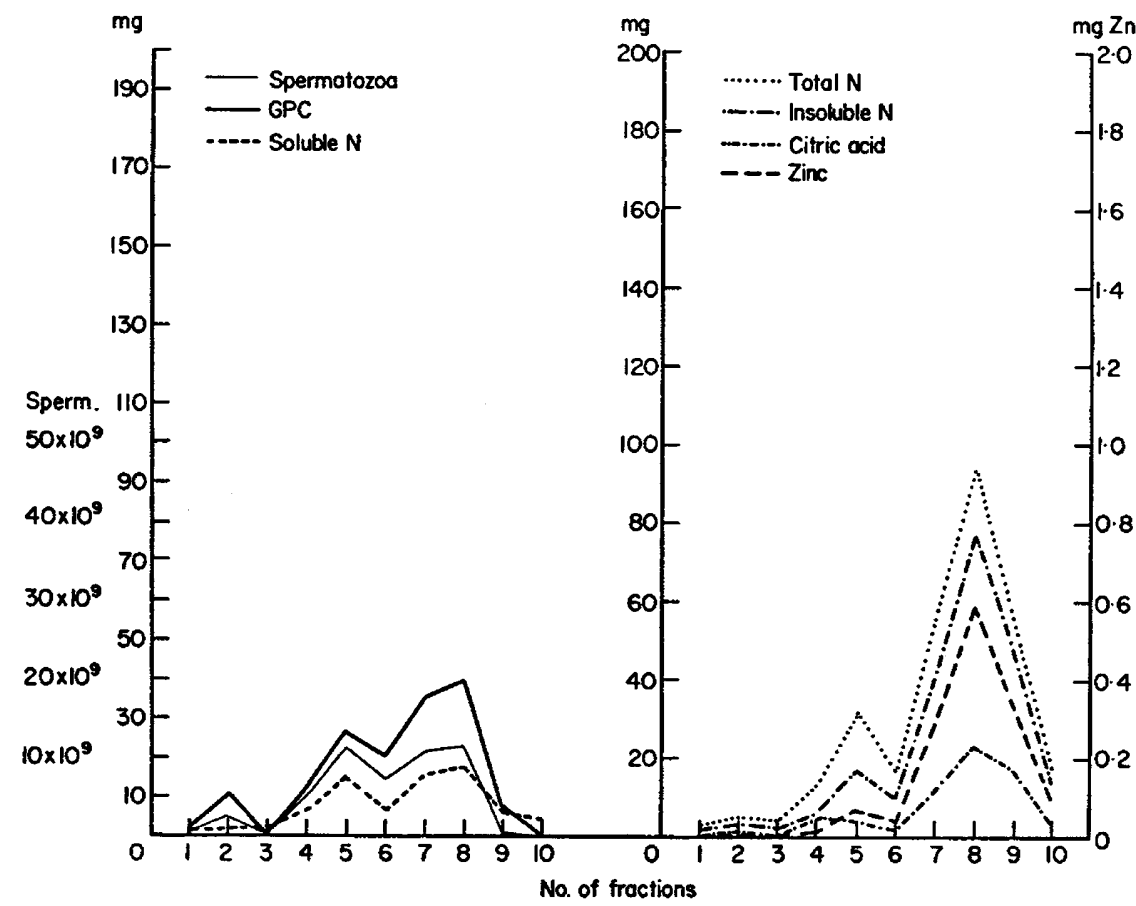

Text-kig. 4. As Text-fig. 1. Values for Boar $W(8 / 7 / 71)$. The vols (ml) of the fractions in order were: $8 \cdot 5,10 \cdot 0,13 \cdot 0,31 \cdot 0,40 \cdot 0,19 \cdot 0,43 \cdot 0,42 \cdot 0,16 \cdot 5$ and $18 \cdot 0$. 


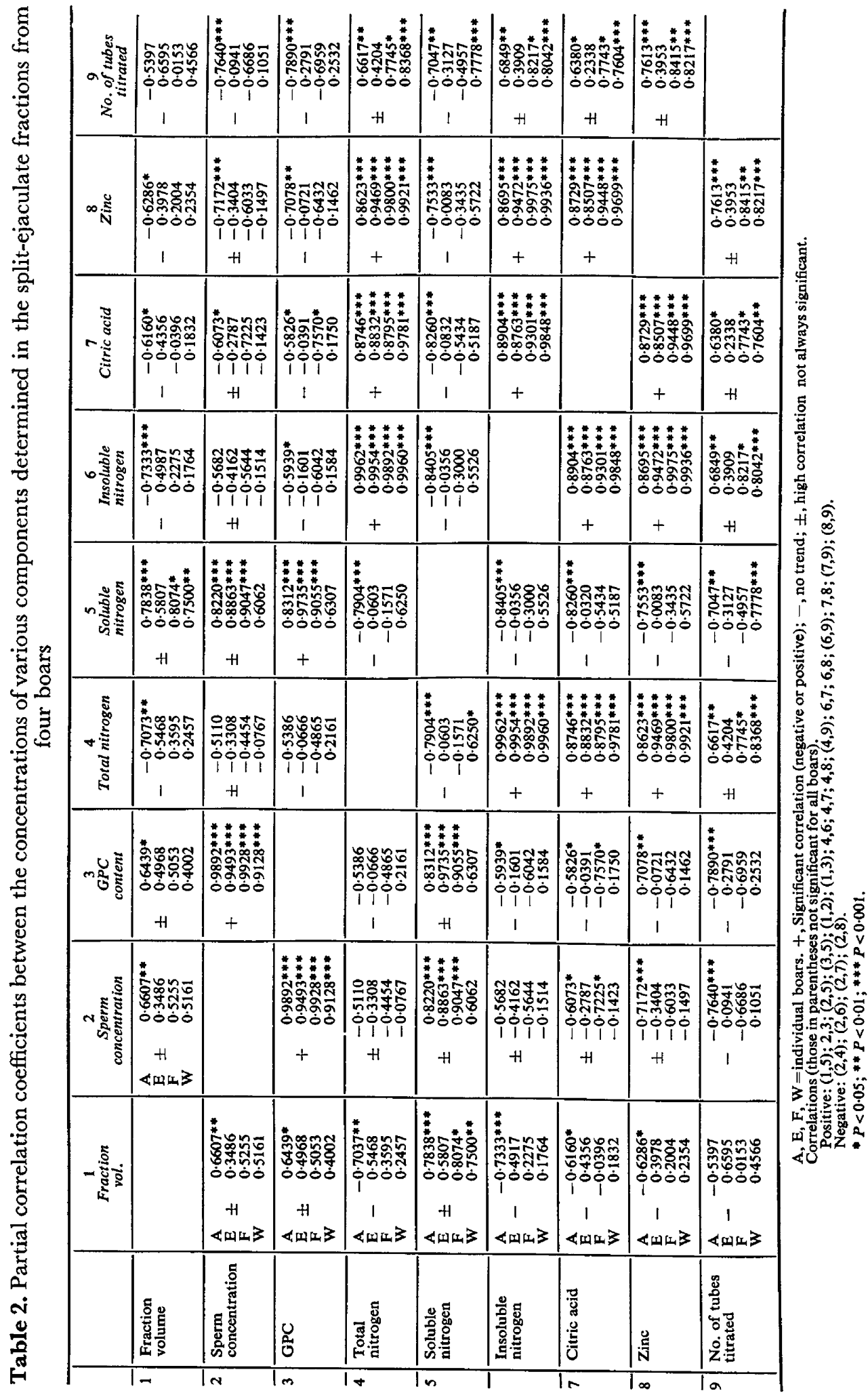

$\mathbf{L}$ 


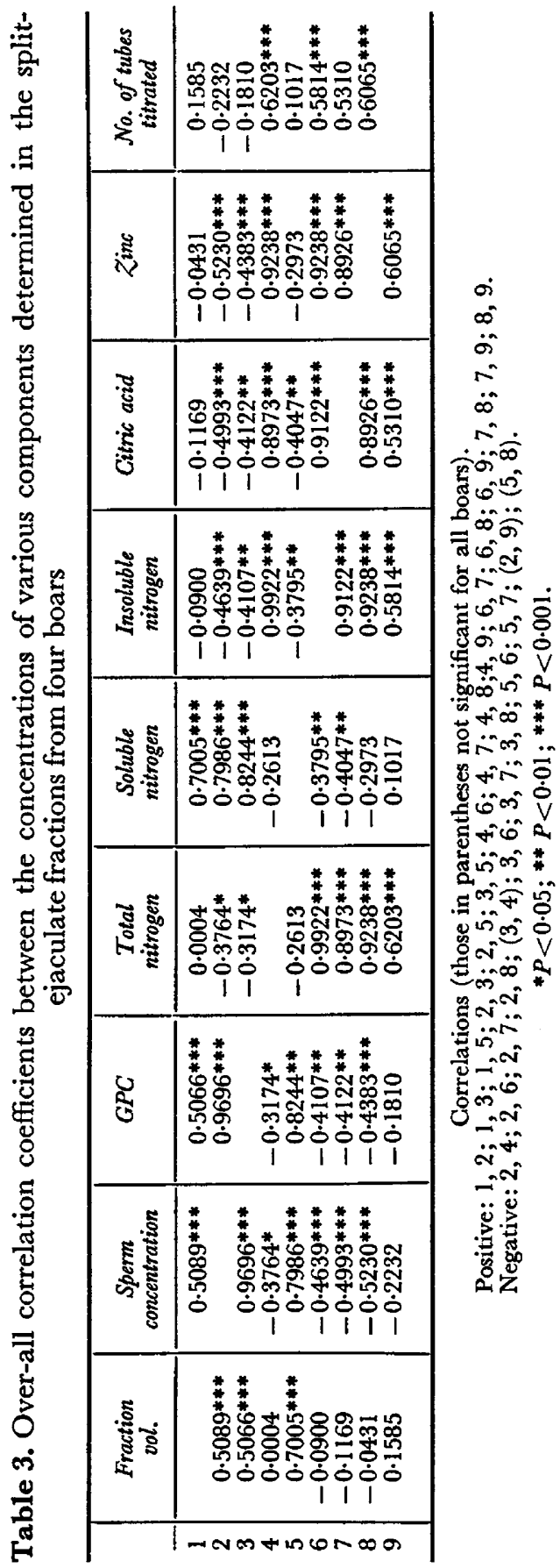




\section{DISGUSSION}

In the present study, many of the results include important constituents of boar seminal plasma other than those described by Glover \& Mann (1954) and Bialy \& Self (1959). Special attention was given to those constituents originating particularly in the EP, such as GPG and ethanol-soluble $\mathrm{N}$ or to those from the VS which had not been studied before: total $\mathrm{N}$, ethanolprecipitable $\mathrm{N}$, zinc and haemagglutinin. In addition, the protein patterns of the various fractions were studied in order to identify proteins particularly characteristic of the secretions of the epididymides or the seminal vesicles.

From all the results of the concentrations of the components in VS, EP and SP presented in Table 1, an attempt was made to calculate the dilutions of VS and EP in the SP, although the sources of the secretory glands were different from those of the SP samples. Moreover, none of the substances was unique to one gland, although the relative VS and EP concentrations of the components differed considerably. The SP contains considerable quantities of urethral gland secretion, the composition of which was not examined. The values obtained for the dilutions of VS and EP in SP are in reasonable agreement with those reported by McKenzie et al. (1938) and Mann \& Glover (1954), but they are greater than those obtained by Einarsson (1971).

The constituents secreted by the two glands can be divided into two groups. In addition to the spermatozoa, the first group, from the epididymis, include GPC and ethanol-soluble N (mainly GPG and free amino acids). The second group, secreted by the seminal vesicles, include citrate, zinc, haemagglutinin, total $\mathrm{N}$ and ethanol-insoluble $\mathrm{N}$. The parameters of each group are positively correlated between themselves and negatively correlated with most of those included in the other group. The correlation coefficients are not significant in all cases for individual animals, but the degree of significance is greater for the over-all correlations.

A study of the concentrations of the components found in the split-ejaculate fractions show that for three boars the GPC and ethanol-soluble N were secreted in the first three or four fractions with the spermatozoa. The VS components were emitted throughout the entire ejaculation and, in Boars $F$ and $\mathrm{W}$, the secretory peak was in the sperm-rich fractions. In the work of Glover \& Mann (1954), the secretory peak of SV components followed shortly after the occurrence of the spermatozoa. In Boar W, the first fractions were almost devoid of any VS components but in the collections from the other boars their appearance as soon as ejaculation commenced was in agreement with the observations of Bialy \& Self (1959). It should also be pointed out that, except for Boar W, some spermatozoa were present from the first fraction onwards and it was difficult to distinguish a pre-sperm fraction.

The time required for the collection of the two ejaculatory waves did not exceed 4 to 5 min. More fractions (twelve) were collected from Boar A than from the others, but the fractions represented four ejaculatory waves. Two of the split ejaculates showed patterns (Boar $\mathbf{E}$ and the first two waves from Boar A) similar to those reported by Glover \& Mann (1954).

In view of the results obtained in this study, it seems reasonable to conclude 
that various animals yield different fractional distribution patterns of the secretions. It seems possible that the results of Glover \& Mann (1954), obtained with many collections from one boar, represented a distinctive distribution pattern characteristic of that particular animal.

The electrophoretic distribution of the VS and SP proteins in the fractions of the split ejaculate agreed with those reported earlier by Lavon \& Boursnell (1971) and Lavon et al. (1972, 1973). The number of proteins in EP (Pl. 1, Fig. 1) was eighteen, and twelve or more of these could be detected in the sperm-rich fraction (Plate 1, Figs 3 and 4). This number was greater than the three proteins obtained by Einarsson et al. (1970) using paper electrophoresis at $\mathrm{pH} 8 \cdot 6$, a pH shown by Lavon \& Boursnell (1971) to be unsuitable for boar SP, VS and EP protein differentiation.

From Fraction 4 onwards (Pl. 1, Fig. 5), the patterns become more similar to that of the VS (Pl. 1, Fig. 14). The haemagglutinin (Lavon et al., 1972) could be identified as a scattered band at the basic end of Fraction I (Pl. 1, Fig. 2), Fractions 3 to 12 (Pl. 1, Figs 4 to 13) and the VS pattern, but was not identified in Fraction 2 (Pl. 1, Fig. 3). These observations are applicable also to some other VS proteins.

It is clear from these results that, while EP components are found in greater concentration in the sperm-rich fraction than in the other fractions or in SP, the sperm-rich fraction still contains a number of VS components. These observations may be relevant to the study of the protective action of phosphatidyl compounds in cold-shock damage to boar spermatozoa (Butler \& Roberts, 1975). The action of phosphatidyl compounds on the zinc-precipitable protein (Boursnell \& Roberts, 1974) in boar seminal plasma has been studied by Roberts \& Boursnell (1974). The work reported in this paper was completed before the zinc-precipitable protein was discovered; it seems most likely that this protein, arising from the seminal vesicles, must also be present in the sperm-rich fraction.

\section{AGKNOWLEDGMENTS}

We are greatly indebted to Miss P. A. Briggs for her very great help with many of the determinations.

We are also grateful to $\mathrm{Mr} \mathrm{P}$. Miles for constructing the apparatus used in the electrophoresis, to Mr R. J. Patman for the photography of the stained electrophoresis plates, to Dr I. Wilmut and Mr J. Doggett for the careful collection of boar semen and to Mr D. J. Kirk and Mr H. C. Toates for arranging the collection of slaughterhouse material.

We would also wish to thank Mr M. Franklin of the A.R.C. Statistics Group, University of Cambridge, for his help in the statistical analysis of the results.

One of us (U.L.) wishes to express his gratitude to the Royal College of Veterinary Surgeons Trust Fund for the award of an MLC/RCVS Senior Fellowship in Animal Health for the years 1970-72, which enabled him to carry out this research. 


\section{REFERENCES}

ARCHIPOVEC, A. I. (1961) The fractionated method of collecting and preserving boar semen. Svinovodstvo, 15, 28-31. Gited from Anim. Br. Abstr. (1961) 29, 2259.

Bertrand, G. \& Vladesco, R. (1921) Intervention probable du zinc dans les phénomènes de fécondation chez les animaux vertébrés. C. r. hebd. Séanc. Acad. Sci., Paris, 173, 176-179.

Blaly, G. \& Self, H. L. (1959) The storage potential and citric acid content of fractionated ejaculates of the boar. F. Anim. Sci. 18, 374-382.

Burss, C. I. (1967) Statistics in Biology, Vol. 2, Chap. 17. McGraw-Hill, New York.

BOURSNELL, J. C. (1967) Boar seminal haemagglutinin. II. Combination with red cells and spermatozoa. 7. Reprod. Fert. 13, 297-314.

Boursnell, J. C., Baronos, S., Briggs, P. A. \& Butler, E. J. (1972) The concentrations of zinc in boar seminal plasma and vesicular secretion in relation to those of nitrogeneous substances, citrate, galactose and fructose. F. Reprod. Fert. 29, 215-227.

BouRsNel.L, J. C. \& BRIGGS, P. A. (1969) Boar seminal plasma proteins. II. Electrophoretic identification of the haemagglutinin. F. Reprod. Fert. 19, 157-166.

Boursnell, J. G., Briggs, P. A., Lavon, U. \& Butler, E. J. (1973a) The association of zinc with some components of boar vesicular secretion and seminal plasma. I. Gel-filtration and dialysis studies. 7. Reprod. Fert. 34, 57-71.

Boursnell, J. G., Briggs, P. A., Lavon, U \& Butler, E. J. (1973b). The association of zinc with some components of boar vesicular secretion and seminal plasma. II. Ultrafiltration and ethanolprecipitation studies. F. Reprod. Fert. 34, 73-77.

Boursnel., J. G. \& Coombs, R. R. A. (1966) A haemagglutinating factor in boar seminal plasma. $\mathcal{F}$. Reprod. Fert. 11, 139-144.

Boursnell, J. G., Hartree, E. F. \& Briggs, P. A. (1970) Studies of the bulbo-urethral (Cowper's)gland mucin and seminal gel of the boar. Biochem. F. 117, 981-988.

Boursnell, J. G. \& Roberts, T. K. (1974) The rôle of zinc in promoting the opalescence and coldprecipitation of boar seminal plasma. F. Reprod. Fert. 36, 91-99.

Brooks, D. E. (1970) Acid-soluble phosphorus compounds in mammalian semen. Biochem. F. 118, 851857.

BUtLer, W. J. \& RoBERTs, T. K. (1975) Effects of some phosphatidyl compounds on boar spermatozoa following cold shock or slow cooling. F. Reprod. Fert. 43, 183-187.

Dawson, R. M. G., MANN, T. \& WhITE, I. G. (1957) Glycerylphosphorylcholine and phosphorylcholine in semen, and their relation to choline. Biochem. F. 65, 627-634.

EINARsson, S. (1971) Studies on the composition of epididymal content and semen in the boar. Acta vet. scand., Suppl. 36, 1-80.

Einarsson, S., Grabo, B. \& Ekman, L. (1970) A comparative study on the chemical composition of plasma from the cauda epididymis, semen fractions and whole semen in boars. Acta vet. scand.11, 156-180.

Gurck, D. (1944) Concerning the reineckate method for the determination of choline. F. biol. Chem. 156, 643-651.

Glover, T. D. (1955) The semen of the pig. Vet. Rec. 67, 36-40.

Glover, T. \& ManN, T. (1954) On the composition of boar semen. F. agric. Sci., Camb. 44, 355-360.

Humphrey, G. F. \& MANN, T. (1949) Studies on the metabolism of semen. 5. Citric acid in semen. Biochem. 7. 44, 97-105.

Johnson, L. A., Pursel, V. G. \& Gerrits, R. J. (1969a) Free amino acids of boar seminal plasma and accessory gland fluids. F. Anim. Sci. 29, 192.

Johnson, L. A., Pursel, V. G. \& Gerrits, R. J. (1969b) Phospholipid fatty acids and free amino acids of boar semen. J. Reprod. Fert. 18, 169.

LASLEY, J. F. \& BOGART, R. (1944) A comparative study of epididymal and ejaculated spermatozoa of the boar. F. Anim. Sci. 3, 360-370.

LAvoN, U. (1972) Gharacterization of boar, bull, ram and rabbit seminal plasma proteins by gel disc electrophoresis and isoelectric focusing on polyacrylamide. F. Reprod. Fert. 31, 29-37.

LAVON, U. \& BourSNEL., J. G. (1971) Gharacterization of boar seminal plasma, vesicular secretion and epididymal plasma proteins by gel disc electrophoresis and isoelectric focusing on polyacrylamide. 7. Reprod. Fert. 27, 227-232.

Lavon, U., Boursnell, J. C. \& Briggs, P. A. (1972) Further characterization of the proteins of boar seminal plasma by isoelectric focusing on polyacrylamide. J. Reprod. Fert. 30, 165-167.

Lavon, U., BrigGs, P. A. \& Boursnell, J. G. (1973) Electrophoresis of protein fractions from boar seminal plasma, vesicular secretion and epididymal plasma. F. Reprod. Fert. 33, 39-51.

LEONE, E. \& MANN, T. (1951) Ergothioneine in the seminal vesicle secretion. Nature, Lond. 168, 205-206. 
LINDNER, H. \& MANN, T. (1960) Relationship between the content of androgenic steroids in the testes and the secretory activity of the seminal vesicles in the bull. F. Endocr. 21, 341-360.

McKenzie, F. F., Miller, J. G. \& Bauguess, L. C. (1938) The reproductive organs and semen of the boar. Res. Bull. Mo. agric. Exp. Stn, 279, 1-122.

ManN, T. (1951) Inositol, a major constituent of the seminal vesicle secretion of the boar. Nature, Lond. $168,1043-1044$.

MANN, T. (1954) On the presence and role of inositol and certain other substances in the seminal vesicle secretion of the boar. Proc. $R$. Soc. B, 142, 21-32.

MANN, T. (1959) Biochemistry of semen and secretions of male accessory organs. In Reproduction in Domestic Animals, Vol. 2, pp. 51-73. Eds. H. H. Cole and P. T. Cupps. Academic Press, New York.

ManN, T. \& Glover, T. (1954) Contribution of the seminal vesicles towards the composition of whole semen. F. Endocr. 10, iv.

Mann, T. \& Leone, E. (1953) Studies on the metabolism of semen. 8. Ergothioneine as a normal constituent of boar seminal plasma. Purification and crystallization. Site of formation and function. Biochem. F. 53, 140-148.

Nelson, M. \& Boursnell, J. C. (1966) Studies on boar seminal plasma proteins. IV. Isolation of factors with haemagglutinating and protein-precipitating activity. Biochim. biophys. Acta, 117, $144-156$.

ROBERTS, T. K. \& BoursnelL, J. C. (1974) The inhibitory action of phosphatidyl compounds on boar seminal haemagglutinin. 7. Reprod. Fert. 41, 489-492.

Speck, J. F., Moulder, J. W. \& Evans, E. A. (1946) The biochemistry of the malaria parasite. 5. Mechanism of pyruvate oxidation in the malaria parasite. F. biol. Chem. 164, 119-144.

Walton, A. (1957) The initiation of motility in mammalian spermatozoa. Stud. Fert. 8, 53-57. 